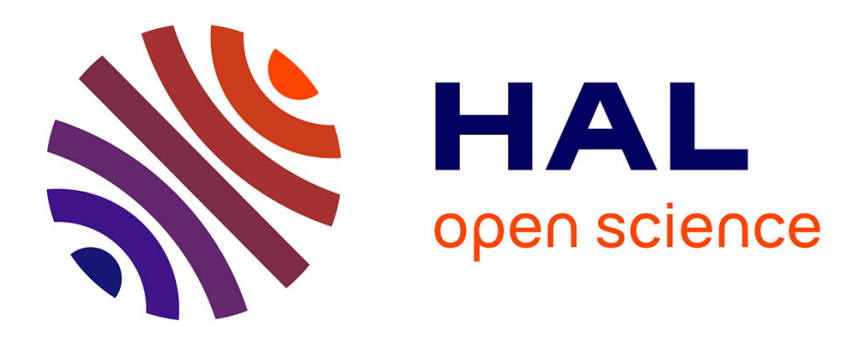

\title{
Migration-related city networks: a global overview
}

Thomas Lacroix

\section{To cite this version:}

Thomas Lacroix. Migration-related city networks: a global overview. Local Government Studies, 2021, 48 (6), pp.1027-1047. 10.1080/03003930.2021.1938553 . halshs-03260094

\section{HAL Id: halshs-03260094 https://shs.hal.science/halshs-03260094}

Submitted on 22 Dec 2021

HAL is a multi-disciplinary open access archive for the deposit and dissemination of scientific research documents, whether they are published or not. The documents may come from teaching and research institutions in France or abroad, or from public or private research centers.
L'archive ouverte pluridisciplinaire HAL, est destinée au dépôt et à la diffusion de documents scientifiques de niveau recherche, publiés ou non, émanant des établissements d'enseignement et de recherche français ou étrangers, des laboratoires publics ou privés. 


\title{
Migration-related city networks: a global overview
}

\author{
Lacroix Thomas, CNRS-Maison Française d'Oxford
}

\begin{abstract}
In recent years, one observes a surge in the number of city networks formed to address the welcoming and integration of immigrant populations. Drawing on a database of over sixty networks, the paper provides a global overview of their different types, scales and activities. Exploring the underlying factors explaining this worldwide expansion, it highlights two sets of congruent dynamics. This phenomenon has been elicited by the longue durée devolution to local authorities of powers and responsibilities pertaining to the management of immigrant populations on the one hand and the recent events of the 2015-2016 'migration crisis' on the other. It is also the outcome of the top-down influence of international organisations (including the European Union) and the bottom-up mobilisations of municipalities facing the growing contradictions between their welcoming responsibilities and security-oriented migration management. In the concluding section, the paper points to the challenges faced by international actors for the building of a 'glocal' migration governance.
\end{abstract}

Keywords: city network; international migration; migration governance; migration policies; integration

There is a certain parallelism between what is happening at the global level for climate change and migration: the vivid dynamism of cities and other local actors responds to the sclerosis of intergovernmental cooperation. Where the dialogue with state authorities becomes difficult, municipalities turn to city networks that may expand globally, and International organisations see in them new partners they can rely upon to overcome the reluctance of states. The scholarship on municipalities in international cooperation is mostly focused on climate change (Bulkeley et al. 2003; Kern and Bulkeley 2009; Fünfgeld 2015). But a similar dynamic is taking shape in the field of international migration. Migration-related city networks have, in comparison, attracted less scholarly attention. So far, the literature on this issue is limited to a few case studies in Europe and North America, focusing on cities in 
networks rather than on the networks themselves. And yet, organisations drawing together cities to talk about and engage with immigration have mushroomed not only in Western countries but also in South America, Africa, Asia and Oceania. The present paper relies on a database of 64 migration-related city networks around the world with the intention of embedding current networking dynamics in a global perspective. Drawing on this database, the second section of this paper presents the lay of the land of migration-related city networks. It brings to the fore two distinct categories: spontaneous networks created to confront security-oriented approaches to immigration and settlement and 'co-opted' networks funded by international organisations. The third section explores a series of hypotheses likely to explain this diversity of parallel trends in different parts of the world. The 'bottom-up' hypothesis supposes that similar policy contexts have been conducive to similar outcomes. Indeed, policy dynamics such as the re-scaling of migration management, the adoption of decentralisation policies and the development of urban diplomacy are observed worldwide. Conversely, the 'top-down' hypothesis brings to the fore the role of international and supranational (including the EU) organisations as the key promoters of similar policy models on different continents. It is argued that the rise of spontaneous mobilisations of local authorities is best explained by the bottom-up hypothesis while the surge of 'co-opted' networks is accounted for by the top-down one. Before examining this global picture, a brief overview of the extant literature on migration-related city networks will show how they have been addressed by academics so far.

\section{Migration-related city networks: a state of the art}

The few existing studies have focused on North America and Europe ${ }^{1}$. In the US, the research has mostly paid attention to Sanctuary cities and Welcoming America. The sanctuary cities

\footnotetext{
${ }^{1}$ For an exception on a Japanese city network see (Tarumoto 2018)
} 
movement gathers cities taking a stand against deportations targeting undocumented people. These cities have, over the years, experimented with various strategies hindering the activities of immigration enforcement administration and provided services and support to undocumented people: creation of municipal IDs, 'don't ask, don't tell' policies, etc. The literature documents sanctuary strategies in the US and beyond (De Graauw 2014; Bauder 2017). They reflect on the Christian genealogy and meaning of urban 'sanctuarity' (Lippert and Rehaag 2012). Others focused on the motives driving cities to join this movement (Huang and Liu 2018; Filomeno 2017b) and the actual effects of their policies (Hudson 2019; Wilcock 2019). Sanctuary cities do not form a centralised organisation but rather an amorphous congregation of like-minded cities. This explains why the research focused on cities in this network rather than on the network itself. By contrast, Welcoming America (WA) is a non-profit organisation that coordinates a network of municipal affiliate welcoming cities (Rodriguez, McDaniel, and Ahebee 2018; Housel, Saxen, and Wahlrab 2018). This organisation was initially launched and framed by civil society activists in 2009 and gradually turned into a US-wide network of cities ${ }^{2}$. The network puts a greater emphasis on the reception of immigrants and access to services than on anti-deportation activism. This initial role of civil society activists is a common trait shared by the sanctuary city movement (whose origin is to be found in the early eighties in the mobilisation of church organisations for Central American asylum seekers). This explains why the US scholarship points to Human rights, religious or ethnic minority organisations as key actors explaining why cities adopt a pro-immigration legislation (Filomeno 2017a; Huang and Liu 2018).

In Europe, a similar dynamic seems to be taking place. Barbara Oomen offers an overview of the networking dynamic at play in Europe (Oomen 2019). The author argues that these

\footnotetext{
${ }^{2}$ A more detailed presentation of this organisation is provided in the last section of this paper
} 
networks signal a decoupling between local and national policies as local authorities promote a more liberal agenda than their national counterpart. The 'decoupling' argument needs to be nuanced. The rise of migration-related city networks in Europe has more to do with the changing features of reception policies than with the security turn of migration policies. Indeed, in recent years, the scholarship has highlighted the so-called "local turn" of integration (Caponio and Borkert 2010), i.e. the greater role played by local authorities in the implementation of integration policies. While in the US, the rise of migration-related city networks is embedded in the confrontational history of the relations between local and federal levels (Varsanyi 2010), the current dynamic in Europe is part and parcel of the (problematic) building of multi-level governance within the European institutional architecture. An array of case studies documents these local policies (Penninx et al. 2016), and the way they relate with national and European ones (Zapata-Barrero, Caponio, and Scholten 2017). In comparison, the role of networks in the dissemination of policy models has received scant scrutiny. Among them, Eurocities attracted the bulk of the scholarly interest (Marlow 1992; Payre 2010; Russeil and Healy 2015). This organisation was created in 1986 with the aim of voicing the concerns and interests of European "secondary" cities (i.e. large cities without the status of state capital). From the nineties onward, it became a strategic partner of European institutions for the implementation of local policies, including on migration and integration.

Like Eurocities, the networks mentioned in the literature are funded by the EU and other international organisations and therefore (even though indirectly) with the money and the blessing of states. Does this mean that the two dynamics in Europe and North America are fundamentally different? A closer look reveals recent converging trends. The rise of militant networks is also observed in Europe, especially in the Mediterranean since the so-called "migration crisis" in 2015-2016 (Furri 2017; Russell 2019; Del Biaggio, Rossetto, and Boria 2019; Lacroix, Furri, and Hombert 2020). The inability of states to bring about an adequate 
response to the inflows of refugees from the Middle East and Africa has spurred a municipal mobilisation with the support of civil society organisations. We will examine, in the following sections of this paper, the scale and nature of this grassroots mobilisation and how it contrasts with the engagements of networks co-opted by international actors around the world.

\section{Migration related city networks: a state of the art}

The intent intention of this work is to move beyond the confines of Euro-American research to explore the scale and scope of migration-related city networks in a global perspective. The database on which this overview is drawn has been marshalled within the framework of two research programmes: the Agence Nationale de la Recherche funded PACE programme (The Politics of Migration and Asylum Crisis in Europe) and the Institut Convergences Migrations programme LOCALACC (les localités urbaines et rurales face aux migrations). It includes information about 64 networks ${ }^{3}$. Data on the list of members, date of creation, aims, practices and organisational framework were assembled mostly through internet searches and the collection of existing listings ${ }^{4}$. Internet searches were undertaken using keywords related to the lexical field of migration/integration in the search engines of international organisations and city associations and also the lexical field of cities/city networks in migration-related agencies. Complementary interviews were undertaken with stakeholders from civil society organisations (Open Society Foundation, Welcoming International, Open Arms), representatives of cities and city networks and public officials involved in the Global Compact process. The main part of the work was undertaken in spring 2019, with occasional updates up to July 2020. The results were compiled in an Excel file including information on

\footnotetext{
${ }^{3}$ The complete listing of organisations and their characteristics is to be found in the online annex of this paper

${ }^{4}$ The listing of networks of local authorities compiled by the UNDP/IOM programme Migration for Development: http://www.migration4development.org/en/content/networks-local-authorities; the report on "municipal migration networks and other models" of the New York City Mayors' Office of Immigrant Affairs; the report titled "Migrations, Cities and Networks : a preliminary assessment" of the City of Montreal and Metropolis.
} 
their date of creation, activities, list of members, partnerships, types and scale. The categories used below are not pre-established categories drawn from the literature, but the outcome of qualitative analysis during the data collection process. The categorial analysis, in turn, helped to refine the data collection in a feedback loop.

This inventory is not comprehensive due to the scattered availability of information, but it is likely to be the largest to date. It includes both specialised organisations whose focus is specifically either integration, migration or asylum and associations with a generalist agenda but that dedicate a part of their activities to international migration. It also includes campaignand project-based networks formed with a limited life span (e.g. the ICMPD 5 -led City-to-City project or the Arrival Cities project supported by the EU programme URBACT in the wake of the 2015 crisis). Another group include institutional forums and representative institutions of local authorities such as the Permanent Congress of Local and Regional Authorities hosted by the Council of Europe or the United Cities and Local Governments (UCLG) at the level of the United Nations. The networks do not necessarily count only municipalities among their members. For example, Diversity Netzwerk, in Germany, also includes higher levels of governments such the Länder of Baden-Württemberg and Saxe. Likewise, some associations combine local authorities and civil society organisations. Networks having shown interest in or accommodated discussion on migration issues but with no durable commitment (as is the case for some climate-change-related networks or the US conference of mayors).

\subsection{The uneven geography of migration-related city networks}

Table 1 presents the spatial distribution of these networks around the world.

Table 1: Spatial distribution of migration-related networks

\begin{tabular}{|l|l|l|l|l|}
\hline & Global & Regional & National & Total \\
\hline
\end{tabular}

\footnotetext{
${ }^{5}$ International Centre for Migration Policy Development
} 


\begin{tabular}{|c|c|c|c|c|}
\hline Europe & \multirow{6}{*}{12} & 15 & 12 & 39 \\
\hline South America & & 4 & 1 & 17 \\
\hline North America & & & 9 & 21 \\
\hline Oceania & & & 2 & 14 \\
\hline Africa & & 5 & 2 & 19 \\
\hline Asia & & 1 & 1 & 14 \\
\hline
\end{tabular}

2019, personal investigations

The table first shows that the development of these networks is primarily a European phenomenon and, to a lesser extent, an African and an American one. However, the spatial architectures displayed on the three continents are very different. In Europe, one can note the importance of regional networks spanning across countries in this area. This reflects the institutionalisation of the European political space for local authorities (Le Galès 2011). The situation is somewhat similar in Latin America where the Mercosur and FLACMA (the organisation representing local authorities at the Mercosur) are important forces behind city networking. Conversely, there is no joint organisation linking Canadian and US networks. In North America, city organising remains state based. An exception is the sanctuary city movement, which has crossed the border to recruit Canadian cities. By contrast, hardly any national network has been identified in Africa (2 against 5 regional). This importance of regional networks may be credited to international organisations on the continent. Two of these are regional branches of the UNESCO network ICCAR (International Coalition of Cities against Racism), and the other two are part of the UCLG, the UN body representing local authorities. There is, therefore, no 'homegrown' regional organisation in this area. The only national organisation dealing with migration issues identified during this study is based in South Africa. The rampant violence against immigrants in this country has urged this country's association of local authorities (SALGA, South Africa Local Government Association) to incorporate this matter in its agenda. Finally, we consider Oceania and Asia. Both continents display hardly any self-contained form of municipal organisation versed in 
migration issues. In Australia and New Zealand, 'Welcoming Australia' and 'Welcoming Communities NZ', are two exceptions. Both organisations are offshoots of Welcoming America and Welcoming International (see below in the last section of this paper).

The geography of migration-related city networks appears just as strongly biased towards Western countries. The increase in South-to-South migration flows (they now represent a share equivalent to the South-to-North flows (World Bank 2016, 11)) has not yet been conducive to the formation of inter-city organisations.

Table 1 also shows the relative importance of global networks (i.e. networks including cities across different continents). They represent nearly a fifth of the total number of networks identified (12 out of 64). This relates to the development of an urban 'paradiplomacy' for cities willing to promote their agenda at the international level (Viltard 2008). It also shows the importance of international organisations such as the UN or UNESCO supporting this global level city engagement. We will address in more detail their role in the second part of the paper.

\subsection{Different forms of organising: grassroots and co-opted networks}

There is not a single way of categorising migration-related city networks. One can differentiate their commitment according to the form of migration they target (refugees, undocumented people, workers and entrepreneurs, women, etc.) or to the agenda they promote (welcoming policies, diversity, integration, etc.). In this paper, I have chosen to distinguish the city networks according to their mode of creation. This highlights the composite dynamics characterising their recent evolution. As mentioned above, the scholarship on migration-related city networks in North America and Europe respectively focuses on two very different kinds of networks. While in the US, the research on sanctuary and welcoming cities focuses on groupings of municipalities collaborating with civil society organisations on a politically tainted agenda, the European organisations investigated tend to 
work within the institutional frameworks of national and European institutions. And we have also already mentioned above the importance of international organisations. Indeed, there is a striking difference between collectives of local governments spontaneously created to cope with migration-related issues and those which have either been created or co-opted by international organisations or national governments. They tend to differ in terms of agenda, activities and scope.

Table 2: Categories of migration-related networks according to their mode of creation, scale and scope of activities

\begin{tabular}{|l|l|l|}
\hline & Grassroots networks & Co-opted networks \\
\hline National level & $\begin{array}{l}\text { Militant networks ANVITA, RECOSOL, } \\
\text { Sanctuary Cities, Welcoming America (US), } \\
\text { Inclusive Cities, Cities for Action, Committee } \\
\text { of cities with a concentration of foreign } \\
\text { population }\end{array}$ & $\begin{array}{l}\text { National associations: Federation of Canadian Municipalities (FCM), } \\
\text { South African local government association, Vereniging van } \\
\text { Nederlandse Gemeenten (VNG), Uganda Local government } \\
\text { association, Diversity Netzwerk, Red de Municipios de Acogida de } \\
\text { Refugiados (RMAR) }\end{array}$ \\
\hline $\begin{array}{l}\text { Transnational } \\
\text { level }\end{array}$ & $\begin{array}{l}\text { Generalist networks: Eurocities, Global } \\
\text { Parliament of Mayors, Fearless cities }\end{array}$ & $\begin{array}{l}\text { Government (UCLG), Permanent Congress of Local and Regional } \\
\text { Authorities, Mercociudades, Metropolis, Urbact, Commonwealth Local } \\
\text { Government Forum, ARLEM }\end{array}$ \\
& $\begin{array}{l}\text { Specialised networks: International Cities of } \\
\text { Refuge Network, Observatoire des Maires } \\
\text { surle Vive ensemble, C-Mise, Welcoming } \\
\text { International, Solidarity Cities, }\end{array}$ & $\begin{array}{l}\text { Specialised networks: International Coalition of Cities Against Racism } \\
\text { ICCAR), Mayoral Forum on Human Mobility and Development, City- } \\
\text { to-City (MC2CM), CLIP, Host Municipalities Learning Network, } \\
\text { Arrival cities, Rumourless cities, Ciudad Solidaria }\end{array}$ \\
\hline
\end{tabular}

Source: personal investigations, 2019-2020. NB: The table only includes a few examples illustrating each category. The full list is available in the annexe.

Table 2 breaks down these two categories of networks according to their geographic scope.

This inventory shows that grassroots activist networks have mushroomed in Europe and elsewhere. These networks have been founded with no or little state support. Their level of militancy and anti-state policy stances vary a great deal. As seen above, sanctuary cities implement measures in blunt contradiction with the policy orientations of the state. Others only fill a void in the absence of national guidance on immigrant welcoming and integration (e.g. the Japanese committee of cities), and others are knowledge production networks (inclusive cities in the UK). But they all produce and disseminate a narrative on immigration that differs from the security-oriented rhetoric that is commonly found at the national level. It 
is worth noting that, in this regard, grassroots networks do not differ from some co-opted ones that are supported by public funding: rumourless cities is a project funded by the European Union (URBACT) aiming at fostering positive migration narratives. Grassroot militant and co-opted networks are not hermetically closed categories but form two ends of a gradient from the most politicised to the most apolitical networks.

Most national 'co-opted' organisations are national associations of municipalities. Most are long-standing generalist associations (the Dutch Vereniging van Nederlandse Gemeenten was created in 1912), others have been recently created to cater for the need of asylum seekers: RMAR was created by the Spanish association of municipalities in reaction to critiques against their passivity during the 2015 'migration crisis'; Diversity Netzwerk is a network supported by the Land of Baden-Württemberg providing support to cities willing to develop a 'diversity policy'. Due to their positioning within the official institutional architecture of the state, they tend to be less politically vocal.

At the transnational level, city networks are much more diverse. Two additional subcategories have been introduced: generalist organisations created to address a variety of issues, including migration, on the one hand, and specialised organisations which have been purposefully created to take action in this domain only, on the other. A few generalist organisations are grassroots organisations created to promote a city agenda at the European (as for Eurocities) or global (e.g. the Global Parliament of Mayors) level. The majority of them are forums, i.e. representative bodies for local authorities attached to large international organisations. I have already mentioned UCLG, based in Barcelona, created in 2004 to connect municipalities around the world and with the United Nations. Likewise, the European Council for Municipalities and Regions (CEMR) and the Permanent Congress of Local and Regional Authorities are part of the institutional constellation of the European Union and of the Council of Europe respectively. 
The specialised networks expanding at a transnational level are more diversified. Some of them are spontaneous militant networks promoting at the international level a proimmigrant agenda. ICORN (International Cities of Refuge Network) is an organisation favouring the resettlement of artists fleeing their country. It was founded in 1993 in the wake of a call by the International Parliament of Writers, launched by internationally renowned intellectuals such as Jacques Derrida. The co-opted networks, by contrast, are generally an outcome of endeavours by international organisations in the area of migration, integration or the fight against racism. This is the case of the Ciudad Solidaria network in Latin America, a group of cities committed to the reception of asylum seekers supported by the High Commission for Refugees (UNHCR). The ICCAR network (International Coalition of Cities Against Racism) is a UNESCO project piloted from Paris. It has branches around the world: Europe, the US, the Middle East, but also in Canada, the Asia-Pacific area, in Latin America and Sub-Saharan Africa. Likewise, the Intercultural Cities Network is a group created and supported by the Council of Europe (White 2017).

This first overview of the different types of networks, be they national or international, shows a double movement in their emergence: a bottom-up movement of cities willing to occupy the international arena; a top-down movement initiated by international organisations aiming at relying on local authorities to enforce their agenda. We will now take a closer look at their respective activities,

\subsection{Activities}

Migration and integration are highly politicised issues with which city organisations engage in varied ways. Migration-related city networks of all kinds focus exclusively on the reception of immigrants and their integration. In other words, they are committed to migration issues as 
receiving localities. No institution seems to be focused on emigration and the benefit that cities are likely to get from their remittances. There seems to be little connection between city networks and broader migration and development agendas. This is all the more surprising given that local authorities engage in various ways in these "migration and development" policies, from the creation of tax-free areas to attracting investment by expatriates (Caglar 2006) to collaborative endeavours between emigrants and municipalities for the implementations of decentralisation policies (Lima 2005) or development projects (Lacroix 2016). Likewise (but this is less surprising), no network aimed at promoting an antiimmigration agenda has been identified ${ }^{6}$.

Barbara Oomen identifies three functions of these networks: diffusing policy models and best practices; symbolic i.e. discourse and identity production; jurisgenerative as they lobby national institutions into adjusting their policies (Oomen 2019). Drawing on information gathered from web searches, Graph 1 partially confirms the importance of these three types of engagement. For each category, it shows the proportion of networks engaged in a given activity. The dissemination of knowledge and best practices is the first form of engagement displayed by city networks: it involves two-thirds of grassroots networks and half of co-opted ones. The importance of the jurisgenerative function is also obvious. The graph distinguishes between three subtypes of activities aiming at altering migration or integration policies: lobbying national or European institutions, the policy orientation of local policies, and setting up policy standards through the writing of charters and 'labelling'. However, the symbolic function of narrative production conveyed by awareness-raising campaigns appears less relevant.

\footnotetext{
${ }^{6}$ An exception is the short-lived "ma ville sans migrant", a network founded by municipalities led by far-right mayors in France. It was created in 2015 against the refugee resettlement programme.
} 
But the study also highlights the stark contrast between grassroots and co-opted networks. Grassroots organisations primarily focus on knowledge exchange ( $68 \%$ of them) and conversely, the provision of project funding is relatively uncommon (18\%).

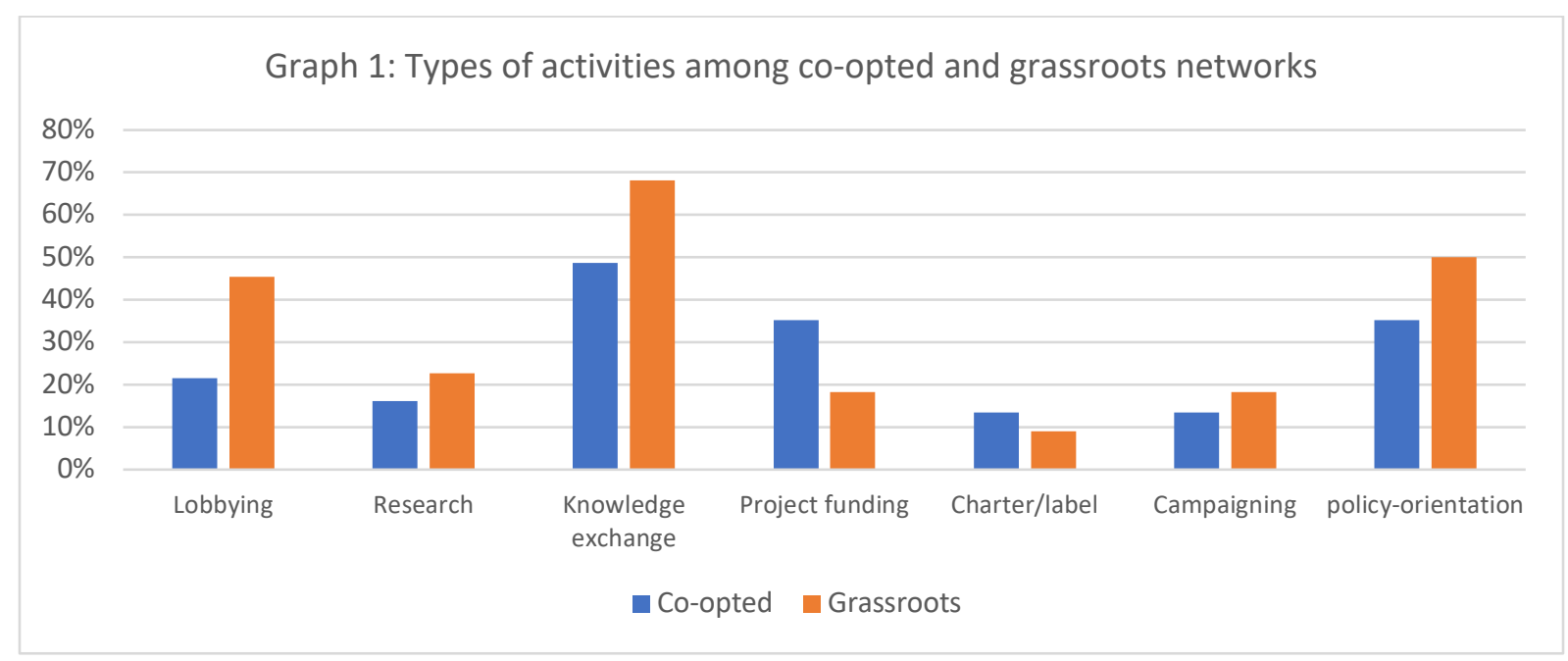

This reflects their lesser financial capacity. But they are more engaged in policyoriented activities. $50 \%$ of them provide guidance to their members to tailor their own legislation, $45 \%$ are engaged in lobbying activities to weigh upon national or international policies (vs $22 \%$ of international organisations-supported associations) and $18 \%$ have supported awareness raising campaigns geared towards the general public (vs 9\%). Also included in this mode of engagement is the attribution of a label or the signature of a common charter. For example, the signature of the ANVITA charter by the local council is a prerequisite to becoming a member of the network. These labels and charters can be interpreted as a form of political statement that local authorities are ready to endorse. Altogether, almost two thirds of the activities implemented by grassroots networks aim at influencing either municipal or national policies or public opinion, and a third of them aim to showcase their projects and 'best practices'. Conversely, the activities of co-opted organisations are more evenly spread across different subtypes of engagement.

Finally, it is worth noting the place of academic research in the activities of these networks. Organisations such as Inclusive Cities or Cities for Local Integration Policies for 
migrants (CLIP) have been part and parcel of research programmes since their formation. Others benefit from the input of experts to guide their activities. Aisling Healy and Sarah Russeil have pointed to the role of academics in the framing of Eurocities' activities (Russeil et Healy 2015). The same could be said of other networks such as intercultural cities, which serves as a crucible for the conceptualisation and testing of the intercultural approach to integration (White 2017).

\subsection{The evolution of city networks}

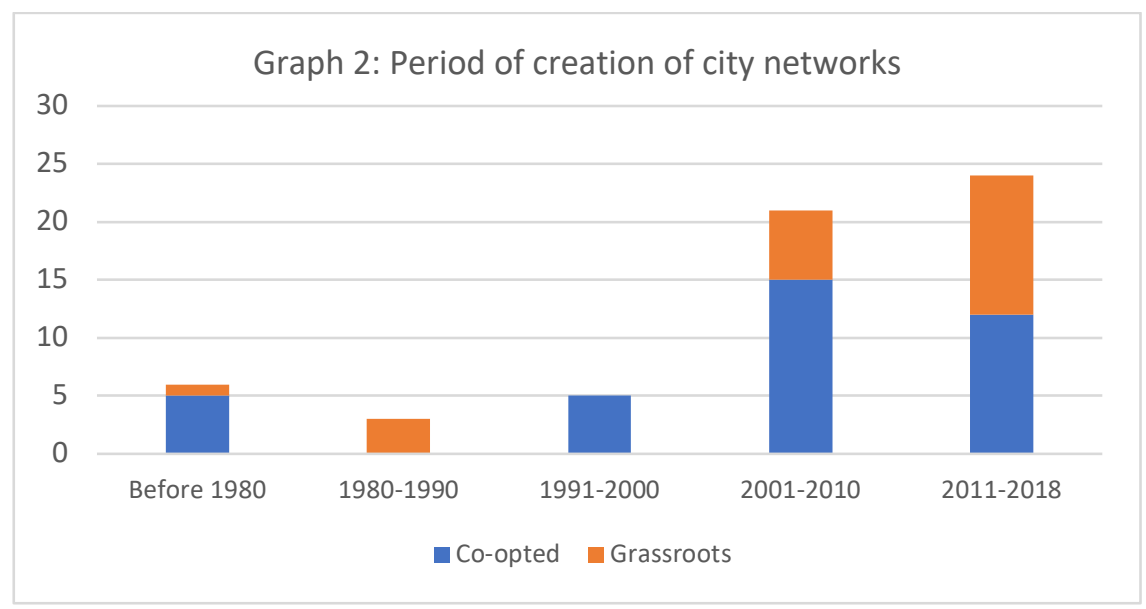

The history of city networks dates back to at least the nineteenth century (Saunier and Ewen 2008) but their focus on migration issues is relatively recent. Graph 2 shows the number of migration-related city networks created over time. It is only in the 2000 s that the phenomenon became sizeable. The database of migration-related networks includes a handful of organisations created before the eighties (e.g. the Brussels-based CEMR or the Dutch VNG), but their involvement in migration issues started in the 1990s or the 2000s. In reality, as pointed out above, the history of migration-related networks only begins in the eighties in the US.

In the nineties, European city networks took shape along with the construction of a European political space, and with the gradual devolution of integration management to local authorities. The Council of European Municipalities and Regions (CEMR) became their 
representative in Brussels, along with the Assembly of Regions (Hooghe 1995; Van der Knaap 1994). And Eurocities became a strategic partner for the formulation and implementation of a European local agenda. However, the number of active cities was limited to a small number of mostly (but not exclusively) left-wing large cities willing to develop their own international agenda: Rotterdam, Antwerp, Birmingham, Lyon, Barcelona...

In the late 1990s/early 2000s a new period characterised by a global shift in the formation of migration-related city networks started. As shown by the graph, this increase in the number of such collectives is primarily driven by the creation of new co-opted networks. However, during the second decade, grassroots networks mushroomed. The following part of this paper examines the motives explaining this evolution.

\section{Unravelling the mechanics of a global expansion}

The analysis of existing migration-related networks around the world highlights a rapid surge in their creation over the last two decades. So far, the Euro- and North America- centred literature has paid attention to the local circumstances which have driven such a dynamic. Highlighting the global scope of this surge requires a link between this phenomenon and global trends. And migration dynamics are not a sufficient explanation. Even if there is an unprecedented volume of migrants in the world, mass population movements in various parts of the world are nothing new: the displacement of exiles during or after the Second World War in Europe or of Southeast Asia in the mid-seventies have not triggered any city-driven reaction to the same extent (Castles and Miller 2009). In order to better explain what is pertinent to our times, different factors need to be brought to the fore: the longue durée of decentralisation policies and the reform of international cooperation that have simultaneously transformed the governance of local affairs and opened a space for international action; the courte durée of migration crises and the security shift of migration policies, on the other hand, which have placed cities at the heart of the conundrums of migration management. 


\subsection{Background factors: the new role of cities on the international scene}

Paradoxically, the presence of cities on the international scene stems from a weakening of their capacity to intervene at the local level. Since the early eighties, the number of countries that have undergone some sort of decentralisation reform has increased dramatically, both in the global North and South (Work 2002). This wave of reform remains skewed, with political decentralisation not being backed up by an adequate fiscal decentralisation. In consequence, local authorities have been granted more responsibilities and powers to support the local economy, but less financial capacity to do so. We have a recent example in the UK, where the localism act in 2011 and City and Local Government Act in 2014 widened their legal capacities, noticeably in the economic domain, but reduced by $40 \%$ the state funding to municipalities, and further to $100 \%$ by 2020 (Lowndes and Pratchett 2012). This type of policy was also applied in Southern countries and often went hand in hand with the growth of a voluntary sector geared towards local development (Gazzotti 2018).

Decentralisation policies are part and parcel of a transformation of local economic governance against the background of state downsizing policies. Local governments are supposed to offset lower public subsidies by valorising their local comparative advantages and making the most of their linkages with local, national and international actors, including migrants. In major sending countries, the growing engagement of municipalities with their expatriates living abroad and the surge of private investment/development projects supported by emigrants are one of the outcomes of such policies (Caglar 2006). In the North, integration policies considering immigrants and immigration as a driving force for local entrepreneurship is also one outcome of this new neoliberal impetus. The approach to urban regeneration proposed by Richard Florida was particularly influential in the US and other parts of the world (Florida 2014). In this perspective, gentrified neighbourhoods become a locale for artists, gay communities, students, start-up entrepreneurs and migrants to mingle, build a 
more positive, cosmopolitan image of the city and bring about economic development. In Europe, 'diversity policies' aiming to 'rebrand' the city image spread in cities such as Vienna or Amsterdam in Europe (Hoekstra, Kohlbacher, and Rauhut 2018)7. The 'local turn' of integration policies (Caponio and Borkert 2010) and the rise of city networks is to be understood against this background.

In parallel to these evolutions happening at the local level, one observes a growing engagement of international organisations with local authorities. The reform of international cooperation has indeed urged development actors to partner with subnational governments. In 2000, the World Bank dedicated a large part of its annual development report to the role of local authorities (World Bank 2000). In 2015, the UN Millennium Development Goals (2015) acknowledges local governments as the matrix of territorial development. In this context, the link between cities and international organisations reached a new level. The creation of the UCLG within the UN framework in 2004 heralds this change. Local authorities have become strategic partners, in particular in domains where intergovernmental cooperation is clogged up. This has been particularly the case on environmental issues (Bulkeley et al. 2003), and it is now the case for migration issues: the number of reports delivered by international organisations on the role of local authorities in migration management signal this interest (International Organisation for Migration 2015; World Economic Forum 2017).

This explains why one observes a multiplication of migration-related networks promoted by international organisations since the early 2000s. The ICCAR network, created with the aim of supporting an anti-racism agenda, was created in 2004. Likewise, the intercultural city network is an initiative of the Council of Europe launched in 2014. The Observatory of Inclusive Cities has been promoted by UCLG since 2012. This latter example also shows that

\footnotetext{
7 and beyond in countries such as Israel (Desille 2019)
} 
generalist networks have developed a specific agenda on migration issues during this period. The two regional branches of UCLG in Africa designed a charter on migration and inclusion in 2018. This growing involvement of generalist city networks in this domain is also signalled by the projects and working groups developed by organisations such as URBACT in Europe, or Metropolis or the Global Parliament of Mayors at the global level. In parallel, with more than half of refugees residing in cities, the reception and management of refugee populations are becoming matters for urban management. Taking stock of recent trends, the UNHCR has supported the creation of city networks in Latin America and Africa: Empowering Refugee Hosting Districts in Uganda was a pioneering HCR project relying on local authorities in 1994. In Latin America, Ciudad Solidaria is a label attributed since 2015 to cities implementing welcoming policies for refugees. IOs have contributed to globalising the involvement of cities in the domain of immigration and integration. And this is particularly the case in Africa and Latin America where they appear as the main driving force behind city engagement.

\subsection{The migration policy context: the local shift migration control and the surge of international civil society activism}

The mutation of local governance under a neoliberal paradigm and the growing connection between local and international authorities are background factors that might be essential but certainly not sufficient to explain the multiplication of migration-related city networks. One also needs to take into consideration the evolution of migration policies. As seen above, cities are acknowledged as a key level of implementation of integration strategies. But at the same time, they have to cope with the effects of stricter migration policies that increase the precarious position of immigrant populations and undermine their capacities to integrate socially and economically in their local setting. Once again, the UK illustrates this paradox: in 2012, the reform of the integration policy aims at 'creating the conditions for integration' but 
in 2014, the objective of the immigration act is to create 'a hostile environment' for undocumented migrants. By and large, local authorities are affected by a movement of ‘interiorisation' of border control (Rodriguez 2014). All over the world, these policies have undermined the social, legal, economic and psychological situation of immigrants.

This tension between restrictive migration policies and the responsibilities of local authorities with regard to immigrant populations is heightened in times of 'crisis'. As mentioned above, in the US, the restrictions imposed by the Reagan administration to refugee migration coming from Central American countries had paved the way for the emergence of the sanctuary city movement. In Europe, the 2015 refugee 'crisis' triggered a coordinated effort to weight upon state policies. A case in point is the creation of the Association Nationale des Villes et Territoires Accueillants (ANVITA) in France. The history of ANVITA is rooted in the dismantling of the Calais 'Jungle' in October 2016. The disbanding of the camp was followed by the resettlement of the immigrant population in other parts of France, including in smaller cities and villages that had not been involved in the inflows of refugees until then. This spurred a demand for more resources, skills and know-how. This mobilisation prefigured the creation of ANVITA in September 2018. The aim of the network is to promote policy and practices articulated around the idea of unconditional welcoming (accueil inconditionnel), against the grain of the selective approach to immigration reception endorsed by the state.

The surge of civil society activism in times of crisis also plays a key role in fostering city engagement. Welcoming America, an NGO already mentioned in this paper, is a good example of this. It was initially an initiative launched by a local voluntary organisation in Tennessee. After 2001, the adoption of the Patriot Act, the revival of the English-only movement and the multiplication of anti-immigrant laws in certain states created an oppressive environment for immigrants. In this context, a small association was created and 
launched a campaign against anti-immigrant prejudice with an emphasis on economic inputs and shared values. The campaign having proved successful, the city of Dayton contacted the association to support the enforcement of a new municipal policy. Dayton thereby became the first 'Welcoming city'. This initiative spread across Tennessee, Ohio and the rest of the US, until Welcoming America was created in 2009, an organisation federating welcoming cities and civil society organisations. It now comprises 93 cities in the US and branches were created in Australia (in 2016) and New Zealand (2018). A further one is currently being created in Germany. This movement was exported thanks to the role of international organisations putting in touch mayors and civil society actors from the US and other countries. The German Marshall Fund is the organisation behind the creation of 'Welcoming Germany'. Civil society organisations have been key drivers for the diffusion of migrationrelated city networks both internally in the US and abroad. The surge of city grassroots networks is linked to the spread of pro-immigrant grassroots militancy locally and internationally.

\section{Conclusion: towards a city-driven management of international migration?}

This paper offers an overview of the surge of migration-related city networks around the world. It shows how grassroots networks with a strong ideological orientation have sprung up mostly at the national level, while regional and international networks signal the development of a city 'para-diplomacy' supported by international organisations. While the former tend to stand at the fringe of the institutional framework of states, the latter are incorporated within broader organisational frameworks of European or international organisations. City networks are therefore an outcome of a double dynamic. They are linked with a top-down movement (from international organisations to cities) which is rooted in a context of glocalisation of international affairs, i.e. a context in which international institutions increasingly rely on and 
partner with local actors. At the same time, they also links with a bottom-up movement caused by the (dis-)articulation of integration and migration policies. Migrants have become part of a new narrative of territorial development. But stricter migration policies and the ensuing precariousness of immigrants' situation have led local authorities to take a stand on migration issues, often with the support of civil society actors. At the core of the formation of migration-related city networks lies an unresolved tension between national migration and local integration policies.

The paper unravels how these different dynamics unfold and evolve in different parts of the world and how they have elicited different forms of networks. While the US has been the stage for the bottom-up mobilisations of municipalities in a policy context hostile to immigrants' settlement, one observes in Europe, firstly, the rise of co-opted networks embedded in the Europeanisation of integration policies and then of grassroots movements advocating more liberal migration policies against the background of the 'migration crisis'. In other parts of the world, city networking is mostly supported by international organisations. There is hardly any grassroots mobilisation, except in major receiving countries such as New Zealand, Australia and South Africa. This might change in the near future in Latin America where cities are coming to grip with populist governments.

The city involvement in migration issues is expanding worldwide. Taking advantage of this trend, international organisations are seeking to enlist local governments into an international migration management framework (Thouez 2020). As with environmental issues, local governments have become allies of the United Nations and other international actors. In 2014, the Global Mayoral Forum on Human Mobility and Development was created with the support of the International Organisation for Migration (IOM) and other international organisations such as UNDP and the World Bank. Following the adoption of the Global 
Compact for Migration in 2018, the Forum has become the third pillar of the institutional framework in charge of migration management, along with the Global Forum on Migration and Development gathering state representatives and the World Social Forum bringing together civil society actors.

The alliance between international organisations, civil society organisations and city networks has made the emergence of a city voice possible. The dynamism of cities contrasts with the sclerosis of states on this issue. This is all the more so given that networks are selective institutions: mayors and municipalities that are positive about immigration are more likely to take an active part in the steering of such networks. However, the shaping of such 'glocal migration governance' will be informed by the initial conditions driving the development of migration-related city networks. In the first place, the international scene is skewed by the weight and importance of Northern associations of municipalities. This dominant position is not specific to the domain of migration (Bouteligier 2013), but it is likely to be particularly acute given the lesser presence of migration-related city networks in Southern countries, and given their diverging interests. This is the first challenge that is to be addressed by the IOM and the Forum for Human Mobility within the framework of governance of international migrations. These organisations plan to build up a common narrative and agenda shared by local authorities from the North and from the South. It remains to be seen if local authorities will succeed where states have not.

The second challenge is the one posed by the policy context of migration management. So far, local and national authorities have maintained a tacit division of labour: while states are to manage flows (immigration), cities are in charge of stocks (reception and integration). But this arrangement has been challenged by the surge of militant city networks whose particularity is to be more vocal on migration policies. This tension has triggered a growing porosity between migration and integration debates. This is the case for grassroots 
organisations in Europe and North America, but it is also increasingly true for 'mainstream' organisations as well: Eurocities, which published a statement on the European Asylum policy in May 2016 or Metropolis (among others), which released a position paper on the 'Global Compact' for migration in December 2016. In this context, the relations between state and local governments are bound to evolve. The legitimacy of the migration management system rests on the capacity of actors to resolve these tensions between states and cities of receiving and sending countries.

Acknowledgement: the author would like to thank the editors of this special issue for their comments and support.

\section{Cited references}

Bauder, Harald. 2017. « Sanctuary cities: Policies and practices in international perspective ». International Migration 55 (2): 174-187.

Bouteligier, Sofie. 2013. « Inequality in new global governance arrangements: the NorthSouth divide in transnational municipal networks ». Innovation: the European Journal of Social Science Research 26 (3): 251-67.

Bulkeley, Harriet, Anna Davies, Bob Evans, David Gibbs, Kristine Kern, et Kate Theobald. 2003. « Environmental governance and transnational municipal networks in Europe ». Journal of Environmental Policy \& Planning 5 (3): 235-254.

Çağlar, Ayse. 2006. « Hometown Associations, the Rescaling of State Spatiality and Migrant Grassroots Transnationalism ». Global Networks 6 (1): 1-22. https://doi.org/10.1111/j.14710374.2006.00130.x.

Caponio, Tiziana, and Maren Borkert. 2010. The Local Dimension of Migration Policymaking. Amsterdam University Press.

Castles, Stephen, et Mark Miller. 2009. The age of migration. Fourth edition. Basingstoke: Palgrave Macmillan.

De Graauw, Els. 2014. « Municipal ID cards for undocumented immigrants: Local bureaucratic membership in a federal system ». Politics \& Society 42 (3): 309-330.

Del Biaggio, Cristina, Tania Rossetto, et Edoardo Boria. 2019. « Mapping Local Resistance to Anti-Immigration National Law: A Carto-Essay ». Journal of Research and Didactics in Geography 1 (juin): 89-98. https://doi.org/10.4458/2252-06.

Desille, Amandine. 2019. « Le paradoxe de la diversité: développement économique et stratification sociale dans les villes de développement en Israël ». SociologieS.

Filomeno, Felipe Amin. 2017a. «The migration-development nexus in local immigration policy: Baltimore City and the Hispanic diaspora ». Urban Affairs Review 53 (1): 102-137. 
Florida, Richard. 2014. The Rise of the Creative Class-Revisited: Revised and Expanded. New York: Basic Books.

Fünfgeld, Hartmut. 2015. «Facilitating local climate change adaptation through transnational municipal networks ». Current Opinion in Environmental Sustainability 12: 67-73.

Furri, Filippo. 2017. « Villes-refuge, villes rebelles et néo-municipalisme ». Plein droit $\mathrm{n}^{\circ}$ 115 (4): 3-6.

Gazzotti, Lorena. 2018. «Local Governance, Civil Society and Migrants' Support to Local Development: Perspectives from Morocco ». In International Migrations and Local Governance, Thomas Lacroix and Amandine Desille (ed.), 79-96. Palgrave MacMillan.

Hoekstra, Myrte S., Josef Kohlbacher, and Daniel Rauhut. 2018. « Migration Governance in Three European Cities: New Local Paradigms? » In International Migrations and Local Governance, par Thomas Lacroix et Amandine Desille, 17-38. Migration, Diasporas and Citizenship. Palgrave MacMillan.

Hooghe, Liesbet. 1995. « Subnational mobilisation in the European Union ». West European Politics 18 (3): 175-198.

Housel, Jacqueline, Colleen Saxen, and Tom Wahlrab. 2018. « Experiencing intentional recognition: Welcoming immigrants in Dayton, Ohio ». Urban Studies 55 (2): 384-405.

Huang, Xi, and Cathy Yang Liu. 2018. « Welcoming cities: Immigration policy at the local government level ». Urban Affairs Review 54 (1): 3-32.

Hudson, Graham. 2019. « City of hope, city of fear: sanctuary and security in Toronto, Canada ». In Sanctuary cities and urban struggles, par Jonathan Darling et Harald Bauder. Manchester: Manchester University Press.

International Organisation for Migration. 2015. « Migrants and Cities: New Partnerships to Manage Mobility ». Geneva: International Organisation for Migration.

Kern, Kristine, and Harriet Bulkeley. 2009. « Cities, Europeanization and multi-level governance: governing climate change through transnational municipal networks ». JCMS: Journal of Common Market Studies 47 (2): 309-332.

Lacroix, Thomas. 2016. Hometown Transnationalism. Long Distance Villageness among Indian Punjabis and North African Berbers. Migration, Diasporas and Citizenship.

Basingstoke, New York: Palgrave MacMillan.

Lacroix, Thomas, Filippo Furri, and Louise Hombert. 2020. « Migration and municipal militancy in the Mediterranean ». EuroMedMig Working Paper Series. Barcelona: GRITIMUPF.

Le Galès, Patrick. 2011. Le retour des villes européennes : Sociétés urbaines, mondialisation, gouvernement et gouvernance. 2e édition. Paris: Les Presses de Sciences Po.

Lima, Stéphanie. 2005. «Les espaces associatifs face aux communes rurales : recompositions spatiales, émergence des acteurs locaux et nouvelles perspectives pour le développement dans la région de Kayes (Mali) ». Emigrés - immigrés dans le développement local, 279-309.

Lippert, Randy, and Sean Rehaag. 2012. Sanctuary practices in international perspectives: Migration, citizenship and social movements. Routledge.

Lowndes, Vivien, and Lawrence Pratchett. 2012. «Local governance under the coalition government: Austerity, localism and the 'Big Society' ». Local government studies 38 (1): 
$21-40$.

Marlow, David. 1992. « Eurocities: From urban networks to a European urban policy ». Ekistics, 28-32.

Oomen, Barbara. 2019. « Decoupling and Teaming up: The Rise and Proliferation of Transnational Municipal Networks in the Field of Migration ». International Migration Review. https://doi.org/10.1177/0197918319881118.

Payre, Renaud. 2010. « The importance of being connected. City networks and urban government: Lyon and Eurocities (1990-2005) ». International Journal of Urban and Regional Research 34 (2): 260-280.

Penninx, Rinnus, Karen Kraal, Marco Martiniello, and Steve Vertovec, éd. 2016. Citizenship in European Cities: Immigrants, Local Politics and Integration Policies. Research in Migration and Ethnic Relations. Abingdon, New York: Routledge.

Rodriguez, Darlene Xiomara, Paul N. McDaniel, and Marie-Dominique Ahebee. 2018. « Welcoming America: A case study of municipal immigrant integration, receptivity, and community practice ». Journal of Community Practice 26 (3): 348-357.

Rodriguez, Robyn Magalit. 2014. « The Interiorisation and Localisation of Border Control: A US Case ». In New Border and Citizenship Politics, Helen Schwenken and Sabine Ruß-Sattar (ed.), 90-102. Migration, Diasporas and Citizenship Series. London: Palgrave Macmillan UK. https://doi.org/10.1057/9781137326638_7.

Russell, Bertie. 2019. « Beyond the local trap: New municipalism and the rise of the fearless cities ». Antipode 51 (3): 989-1010.

Russeil, Sarah, and Aisling Healy. 2015. «Quelles expertises urbaines pour une 'Europe des villes' ? Le réseau "Eurocities" et ses experts ». Politique Européenne 49 (3): 54-83.

Saunier, Pierre-Yves, and Shane Ewen. 2008. Another global city. Historical Explorations into the Transnational Municipal Moment, 1850-2000. Basingstoke, New York: Palgrave Macmillan.

Tarumoto, Hideki. 2018. « The Limits of Local Citizenship Policies in Japan ». In International Migrations and Local Governance, Thomas Lacroix and Amandine Desille (ed.), Palgrave, 191-213. Migration, Diasporas and Citizenship. Cham: Springer.

Thouez, Colleen. 2020. "Cities as emergent international actors in the field of migration: evidence from the leadup and adoption of the United Nations Global Compacts on Migration and Refugees" Global Governance 26(4): 650-672

Van der Knaap, Peter. 1994. "The committee of the regions: The outset of a "Europe of the regions"? » Regional \& Federal Studies 4 (2): 86-100.

Varsanyi, Monica. 2010. Taking local control: Immigration policy activism in US cities and states. Stanford: Stanford Univ Press.

Viltard, Yves. 2008. « Conceptualiser la «diplomatie des villes» ». Revue française de science politique 58 (3): 511-533.

White, Bob W. 2017. Intercultural cities: Policy and practice for a new era. Global Diversities. New York; London: Springer.

Wilcock, Cathy. 2019. « Hostile Immigration Policy and the Limits of Sanctuary as Resistance ». Social Inclusion 7 (4): 141-151.

Work, Robertson. 2002. « Overview of decentralisation worldwide: A stepping stone to 
improved governance and human development ». In Second International Conference on Decentralization, "Federalism: The Future of Decentralizing States?", 20. Manille.

World Bank. 2000. « Entering the 21st century. World Development Report 1999/2000». Washington D.C.: World Bank.

—. 2016. « Migration and Remittances Factbook $2016 »$. Washington D.C.: World Bank Publications.

World Economic Forum. 2017. « Migration and Its Impact on Cities ». Geneva: World Economic Forum.

Zapata-Barrero, Ricard, Tiziana Caponio, and Peter Scholten. 2017. « Theorizing the 'Local Turn' in a Multi-Level Governance Framework of Analysis: A Case Study in Immigrant Policies ». International Review of Administrative Sciences 83 (2): 241-46.

https://doi.org/10.1177/0020852316688426. 